\title{
Risk Management and Insurance of Small and Medium Scale Enterprises (Smes) in Nigeria
}

\author{
Azende Terungwa
}

Department of Accounting, Benue State University, Makurdi, Nigeria

\begin{abstract}
This study assesses the financing options available to Small and Medium Scale Enterprises (SMEs) in Nigeria to identify the one that is most patronized by them, using Benue and Nasarawa States as case study. Mean scores and standard deviation were used to present and analyze the primary data obtained via questionnaires. Correlation was used to substantiate whether there is similarity in the inherent identified problems of each financing option. Simple percentages combined with mean scores were used to test hypothesis one while Chi-square was used to test hypothesis two. The result shows that SMEs are significantly financed by informal sources of finance than the formal sources of finance. The formal financing options are more organized and as such avoid SMEs because of their risky nature. Predominant SMEs are lacking in good risk management strategies and insurance cover which is why their funding problem still subsists. The major recommendation is that Capacity building and sensitization programmes for all registered SMEs should be put in place by government to enlighten them on the benefits of good risk management and insurance of their businesses. Both the government and the banking sector should mutually agree on a credit guaranteed scheme strategy that will incorporate a risk-sharing arrangement as a way of encouraging the banks to channel funds to the SMEs sub sector for their growth and development which would translate into the national economic growth and sustainable economic development of Nigeria.
\end{abstract}

Keywords Small and Medium Scale Enterprises, Formal and Informal Financing Option, Risk Management, Insurance Cover, Sustainable Economic Development

\section{Introduction}

Every purposeful and responsible government quest to improve the living standard of its people on a continual basis. It is in this vein that the present administration of Dr. Goodluck Ebele Jonathan is of the vision that, by the year 2020, Nigeria would be one among the first 20 largest economies of the world otherwise called vision 20-20-20. This is achievable if it is premised on a sound and committed economic policies implementation in the country. It must be emphasized that it is while attending to small matters that bigger things are created (Sule, 1986). Vision 20-20-20, for example, is economically a big and remarkable thing, but unless Nigeria attends to smaller economic matters, she cannot achieve it. There is, therefore, the need to assess the country's stand now to see if she is heading to the right direction in actualizing her dreams.

Small and Medium Enterprises (SMEs) play important roles in the economic growth and sustainable development of any economy (Ariyo, 2005). They may look small or inconsequential but are actually the foundation of any econ-

* Corresponding author:

tazende@yahoo.com (Azende Terungwa)

Published online at http://journal.sapub.org/ijfa

Copyright (C) 2012 Scientific \& Academic Publishing. All Rights Reserved omically stable nation. The potential benefits of SMEs to any economy include contribution to the economy in terms of output of goods and services; creation of jobs at relatively low capital cost; provision of a vehicle for reducing income disparities; development of a pool of skilled and semi-skilled workers as a basis for future industrial expansion, among others.

According to NCI (2003), a small-scale industry is an enterprise with total cost (including working capital but excluding cost of land) above N1.5 million but not exceeding N50 million, with a labour size of between 11 and 100 workers, while the medium-scale industry has a total cost (including working capital but excluding cost of land) above N50 million but not exceeding N200 million, with a labour size of between 101 and 300 workers.

Kpelai (2009) asserts that SMEs are the engine room for the growth of any developing economy, because they form the bulk of business activities in developed and developing economies like Nigeria. Many economies like Canada, Croatia, etc have acknowledged that SMEs are crucial for industrial restructuring and have formulated national SME financing policies, targeted at developing the sub-sector. However, the small business' contribution to macro- economic development is inhibited by the fact that they have no, or only overpriced, access to finance institutions and other services (Schneider-Barthold, 2002). More so the accessi- 
bility to funds and the cost of raising them have remained issues limiting the in-capitalisation requirement leading to premature collapse of SMEs (Mambula, 2002).Funding has therefore remained one of the key managerial problems that keep confronting business enterprises in Nigeria today.

The two fundamental financing concepts of SMEs, the formal and informal forms of financing, have been identified by previous researchers, scholars and practitioners (Gelinas, 1998; Aruwa, 2004a). The formal forms of financing are the ones regulated by the government, while the informal forms of financing are not so regulated by the government.

To Gelinas (1998) and Aruwa (2004a) among the most popular of the formal sources of financing, are the commercial banks and development banks for enterprises. The informal sources on the other hand comprise borrowing from friends and relatives, and cooperative credits. With the availability of these identified financing options SMEs still have problem of financing.

The problem of SME financing has received the most tremendous research efforts from researchers. Some notable works in this respect include Aernold (1998), Anic and Paus (1998), Inang and Ukpong (2002) and Aruwa (2004b). In their findings, four problems in financing SMEs have become recurrent: the cost of capital; risk; the inappropriate terms on bank loans; and the shortage of equity capital. Over the years government has enacted various policies and introduced schemes aimed at financing SMEs. However it is worrisome to note that SMEs up till date are starved of funds and the financing problems keeps reoccurring. Why this recurrent financing problems of SMEs in the face of the formal and informal financing options available?

SMEs appear risky as found out by scholars as stated above. They are therefore not attractive to investors. The biggest risk facing SMEs today are financial and strategic risks. For financial risks, cash flow is especially a concern; businesses ought to consider the source of their money in order to keep the lights on to pay employees, operate and grow. Strategic risk on the other hand includes competition and economic conditions. No business is free of risk, it certainly face some degree of risk; some of the risk are controllable with respect to the appropriate action taken against it whereas some are largely unpredictable and as such uncontrollable. Most business owners are aware of this and plan carefully before commencing operation but such a business still face closure due to some factors beyond its control like earthquakes, fire outbreak, tsunami, flood, social unrest, intentionally inflicted damages, etc. Having said all these, it must be emphasized that the business owner, who carefully identifies the risk of its business and take appropriate action accordingly to mitigate the risk, will surely be successful in that business. Insurance gives a cover over that which is insured. Good risk management and insurance cover can give an assurance to investors and hence reduce risk of a business. What therefore remains is whether SMEs do know their risks and whether they know that most of them are insurable. This is because you cannot control what you do not know.
Small and Medium Enterprises Equity Investment Scheme-SMEEIS is a product of formal financial institutions put in place to finance SMEs through a venture capital financing. This initiative is seemingly attractive as a reliable formal source of financing for SMEs since it involves all the banks in Nigeria and the Central Bank of Nigeria monitors the banks to enhance compliance. SMEEIS has failed to solve this financing problem in Nigeria Aruwa (2004).

The aim of this paper is to critically look at the financing options available to SMEs in Nigeria and to determine whether risk management and insurance of SMEs will mitigate this recurrent funding issue. The hypotheses tested in the study are stated in the null form as follows: $\mathrm{HO}_{1}$ SMEs in Nigeria are funded significantly by formal sources rather than informal sources. $\mathrm{HO}_{2}$ : Good risk management techniques and adequate insurance cover for SMEs will help improve their funding.

\section{An Overview of Risk and Insurance of Smes}

From the findings of some notable works such as Aernord (1998), Anic and Paus (1998), Inang \& Ukpong (2002) and Aruwa (2004b), risk is one of the recurrent problems that makes SMEs unattractive to investors. Risks are defined as the chance of something happening that will impact upon objectives (Aernorld, 1998). Risk is a part of every day life. There are many types of risk that will be encountered in business. Some are controllable while others are not. Some are foreseeable while some are unforeseeable. Some have minimal impact on the business while some threaten the longevity of a business. SMEs are businesses in the private sector and they cut across all industries. The nature of risk therefore varies according to the industry in question. The onus is therefore on the owner to identify the risk prevalent in his business and make efforts to embark on good management techniques. Risk management is an integral part of good business governance. It is simply protecting the business from possible negative occurrences, as well as recognizing opportunities and capitalizing on them when they arise (Aruwa, 2004b). Risk management is the way in which adverse effects from risk are managed and potential opportunities are realized (Vaughan, 1997).

The list of risk that SMEs face is endless because this is one sector where entry and exit is uncontrollable. Having said that, these are some of the risk that SMEs face: changing taste and preferences, start ups business, trend of things in an economy, actions by your competitors, overhead cost, cost of equipments, expected sales volume, salary cost, taxes, obsolesce, flood, fire outbreak, tsunami, earthquake, machine breakdown, cash flow problem, intentionally inflicted damages, potential permanent loss of customers to competitors, management risk, marketing risk, reputation risk etc. This is just part of the in exhaustive list of possible risk for SMEs. Some here are predictable and to some extent controllable while others are unpredictable and uncontrollable. It 
is proper to manage the ones that are predictable and take cover on the unpredictable ones. The first step to effective risk management is to identify them (Azende, 2011a). You can identify them by taking a closer look at what your business does and then intelligently asking yourself what could possibly impede the realization of objectives of the business. Answers will definitely come up and when appropriate actions are taken, it will help mitigate risk.

Risk can be avoided by simply not undertaking that activity likely to generate the risk. This should be done when there are no readily available control measures or there are not strong enough to reduce it to an acceptable level. According to Inang \& Ukpong (2002) uncontrollable or inappropriate risk avoidance may lead to organizational avoidance, resulting in missed opportunities and an increase in the significance of other risk. Taking cover on the other hand will be for the owner to visit insurance outfits and then hand over all insurable risk to them. Even if there are some that are not readily insurable, you can approach an insurance agent to help you access the impact of a foreseeable loss on the type of business you do. It is with the agent's expertise and experience that will aid this analysis hence impossible to overlook any exposures. Small business could self-insure by saving money for possible future losses. This in itself is not enough in so far as it is not to the knowledge of investors that such a business is doing this (Azende, 2011b).

Running a business with basic insurance is a very smart way in managing the identified risk and reduces uncertainty (Douglas, 2009). Insurance is defined as Insurance is defined as the equitable transfer of the risk of a loss, from one entity to another, in exchange for periodic payment. It is a risk management strategy that protects the insured from risk for a specified fee. It is a risk treatment option which involves risk sharing. There are different types of insurance policies just as there are different risk exposures. This paper mentions liability insurance; business property insurance, workers compensation insurance, health insurance, life insurance etc. Small businesses no matter the type are exposed to liabilities. So there is need for protection against them. Liability insurance is shifting financial liability for covered claims from the insured business owner to the insurance company. In this instance any damage or injuries that occur to a third party while on your property, or as a result of using your product or service, are paid for by the insurance provider (Vaughan, 1997). Examples of liability insurance for small business are General Liability Insurance, Public Liability Insurance, Professional Liability Insurance, Product Liability Insurance and Employers Liability Insurance.

For a small business, its properties need to be protected since efforts to replace are more demanding on the business. This is why business property insurance is also necessary. Sickness is an unpredictable occurrence and when it strikes a key employee then the business suffers. Health insurance can make available funds to take care of an employee when the need arise. SMEs should know that insurance policies can be changed to suit their needs. If a policy does not cover a particular risk in a particular business, the owner can demand to have a clause included in it to suit his. The main thing to be understood is that an insurance policy no matter the type should be adequate. This means over-insure and under-insurance is not healthy for any business. The solution is to contact experts before taking decision.

Having said all these, business owners should know that risk management is so fundamental and it should be considered right from the start of the business. Good risk management protects the reputation of the company and helps it plan for contingencies ensuring enhanced profitability and longevity of the business. Most business plans do not adequately address business risk. This paper is a wake-up call to help stimulate the thought process of business owners to understand their business for enhanced decisions. Decisions here could mean among other things on how you allocate your resources and time having understood your business and the risk that is exposed to it.

Giving the vital role played by SMEs in the economic development of any nation, the sector has wide range of expectation by its stakeholders; for example, government expect SMEs to survive, grow and be productive to stabilize the economy, customers expect that the products offered by SMEs should be there for them whenever they need them, big industries that use the products of SMEs are counting on them for their production, investors expect SMEs to operate profitably to enhance the security of their funds. The issue of risk and its management is therefore appropriate for SMEs for the overall interest of the stakeholders and the economy as a whole.

\subsection{Theoretical Framework and Literature Review}

A well functioning financial system is a key enabler of economic growth. SMEs are an important part of Nigeria's economic growth and development and bank lending is the primary source of external finance for SMEs. Therefore, it is important that the banking sector responds efficiently and effectively to the needs of SMEs. According to Ohanga (2005) there are a number of features of lending generally which potentially could affect the efficiency of the market for lending.

Information Asymmetry is a situation where business owners or managers know more about the prospects for, and risks facing their business than do lenders. Where information asymmetries exist, bank lending theory predicts that lenders may respond by increasing lending margins to levels in excess of that which the inherent risks would require. Bank lending theory also suggests that banks may also curtail the extent of lending - credit rationing - even when SMEs would have been willing to pay a fair risk-adjusted cost of capital. The implication of raising interest rates and/or curtailing lending is that firms will not be able to finance as many projects as otherwise would have been the case. Information asymmetry is more acute in case of SMEs because their relative size makes them economically unattractive to banks since they are unable to accurately gauge the level of risk involved in lending to SMEs (Ohanga, 2005). 


\subsection{Pecking Order Theory/Hypothesis of lending}

Ohanga (2005) asserts that, from the borrower's perspective, if faced with a cost of lending that is above the true risk-adjusted cost, the borrower will have incentives to seek out alternative sources of funding. Bank lending theory suggests that, where information asymmetry and moral hazard are prevalent, firms are likely to fund themselves firstly from retained earnings and then from bank debt rather than issuing equity. This is referred to as the pecking order theory/hypothesis. The theory further suggests that the mix of debt and equity should be the cumulative result of hierarchical financing decisions over time.

Evidence around the world indicates that small scale enterprises provide an effective means of stimulating indigenous entrepreneurship, enhancing greater employment opportunities per unit of capital invested and aiding the development of local technology (Sule, 1986: World Bank 1995). Through their wide dispersal, they provide an effective means of mitigating rural-urban migration and resource utilization. Furthermore, by producing intermediate products for use in large scale enterprises, SMEs contribute to the strengthening of industrial linkages. These explain the increased interest which developing countries have shown in the promotion SMEs since the 1970s (Ekpenyong and Nyong, 1992).

Akabueze (2002) asserts that the significance of finance in the drive for economic growth is fairly well established and generally accepted. For instance, the take-off and efficient performance of any industrial enterprises, be it small or large, will require the provision of funds for its capitalization, working capital and rehabilitation needs, as well as for the creation of new investments. Apart from entrepreneurship, funds are required to bring together the other factors of production - land, labour and capital - before production can take place. Provision of funds to the industrial sector, particularly, for the SMEs has, therefore, been of prime interest to policy-makers in both the public and private sectors. Aladekomo (2003) notes that successive governments in Nigeria have, since the last three decades, shown great interest in financing of SMEs, by establishing specialized banks and other credit agencies/schemes to provide customized funding to the sub-sector to enhance growth and stability. In addition to these, programmes like the Nigerian Directorate of Employment (NDE), Better Life for Rural Women, Family Support Programme, Child Care Trust, People's Bank, National Poverty Eradication Programme (NAPEP), to mention a few, have been introduced.

The impact of all existing credit schemes to SMEs, in terms of providing funds for meaningful and sustained development among the SMEs, had hardly been noticeable. These credit schemes either have a direct or indirect link with banks. The banks by their nature and position in the economy, therefore, remain the known formal source of finance for enterprises (Agumagu, 2006). It is disheartening to know that a 2001 World Bank survey on Nigerian firms showed that although $85 \%$ of the firms had relationships with banks, most of them had no access to their credit. This explains why SMEs in Nigeria represent about $90 \%$ of firms in the Nigerian industrial sector on numerical basis but regrettably contribute as low as one percent to GDP in contrast to countries like Indonesia, Thailand and India where SMEs contribute almost $40 \%$ to GDP (HPACI, 2002).

The failure of most of the schemes and the need for a sustainable source of financing SMEs, therefore, necessitated the recent Central Bank of Nigeria (CBN) inspired Banker's Committee initiative which is aimed at committing the banking industry to the provision of finance and other ancillary support to the sub-sector via an equity participation scheme.

\subsection{Bank Lending and SMEs Development in Nigeria}

SMEs are crucial catalysts for economic development (Aruwa, 2006). Banks provide a nation with a function of pooling scattered resources from surplus to deficit units so as to promote investment innovation, productivity and consequently growth and development. The banking industry in Nigeria dominates the financial system (Agusto, 2000). Berger et al (2001) maintains that a well functioning financial system contributes to investment and economic growth. Every enterprise at its onset, before standing firm on its feet, needs borrowing. The first place that they need to go and borrow at those times is the banks.

According to elementary corporate finance theory, an investment project should be undertaken whenever its net present value is positive. This assumes that the capital outlay is not exhaustive. Firms do any volume of investment, and so where the firms do not have adequate capital to embark on any level of investment, there is need for capital borrowing (Mainoma, 2005). This shows that even if an enterprise is strong and firmly rooted, it still does not stop borrowing, because it can embark on a very large scale investment more than it currently does, if it can get the required capital. When funding becomes a major problem for such enterprises, nothing else works. This is because other problems which emerge later in an enterprise's lives that are being tackled as natural problems which come after its funding. This in turn hinders the growth and development of the economy.

Njoku (2007) postulates that to forestall the imminent capital flight from the real sector to the banking sector, banks should begin to take second look at the industrial sector in terms of lending operations. He continues that banks should plough back a large proportion of the money available to them to the real sector of the economy as long-term loans at rates not exceeding $5 \%$. This he said will encourage industrialists not only to remain in their present businesses but also to achieve their business expansion targets.

Small and medium scale enterprises dominate the private sector of the Nigerian economy, but almost all of them are starved of funds (Mambula, 2002). The persistent lack of finance, for establishment and operation of SMEs occasioned by the inability or unwillingness of the deposit money banks to grant long term credit to operators of the real sector 
of the economy, led to the establishment of development finance institutions and the introduction of numerous funding programmes for the development of SMEs in Nigeria. In spite of these institutions and funding programmes, there continues to be a persistent cry against inadequate finance for the development of the SMEs in the country.

The CBN (2008) shows that commercial and merchant banks loans and advances to SMEs have been decreasing over the years. The statistics show thus; commercial bank's loans to SMEs as a percentage of total credit decreased from $48.8 \%$ in 1992 to $22.22 \%$ in 1994 . The trend increased marginally to $22.9 \%$ and to $25.5 \%$ in 1995 and 1996 , respectively. There was a sharp reduction from $25 \%$ to $17 \%$ in 1997 , and the decrease continued till it reached $0.2 \%$ in the year 2008. Similarly, merchant banks loans to SMEs as a percentage of total credits reduced from $31.2 \%$ in 1992 to $9.0 \%$ in 2000 (Akabueze, 2002). The continuous decrease in commercial and merchant bank's loans to small scale enterprises can be attributed to lack of collateral from the SMEs to secure the loans and the high lending rates from the banks.

\subsection{Main Sources of Financing SMEs in Nigeria}

The importance of finance to business organisation cannot be over-emphasised. Business finance is however, not easy to come by especially in respect of SMEs. Yet they require funds from every source available to meet their asset needs, working capital needs, and for expansion. According to Ekpenyong and Nyong (1992), there is wide consensus in Nigeria that government policies are skewed in favour of the formal sector to the detriment of the informal sector. This skewness is to the great disadvantage of SMEs in Nigeria since they are more disposed to the funds of the informal sector.

\subsubsection{Formal Sources of Financing SMEs}

The commercial banks, merchant banks, and development banks provide the formal sources of finance to SMEs. The financial system in Nigeria is not in short supply of liquidity, but banks have been very reluctant to grant loans to SMEs, which they regard as a high-risk sector. Most of the banks would rather pay the penalty imposed for not meeting the minimum exposure to preferred sectors of the economy than actually run the risk of being exposed to them.

According to Ojo (1984), the sources of investment finance for SMEs include owner's savings and assistance from banks, government institutions, local authorities, co-operative societies, relatives and friends, and moneylenders. The study shows that almost all the funds came from personal savings $(96.4 \%)$ with about 3\% from the informal sector and $0.21 \%$ from the formal financial institutions. This trend is further established by a 1983/84 study by the Nigerian institute for Social and Economic Research (NISER). NISER findings show that about $73 \%$ respondents raised their funds from personal savings, while only about $2 \%$ obtained their funds from the formal financial institutions.

\subsubsection{The Small and Medium Industries Equity Investment Scheme (SMIEIS) Fund}

In Nigeria, the formal financial institutions have been organised to finance SMEs through venture capital financing in the form of a SMIEIS fund. This was in response to the Federal government's desire to promote SMEs as vehicles for rapid industrialisation, sustainable economic development, poverty alleviation and employment generation. Venture capital financing supplements or takes the place of credit facilities that the conventional banks are unwilling to give. The provider of the funds may initially part with the funds as a loan, but specifically with the idea of converting the debt capital into equity at some future period in the enterprise. The return from such investment should be high to compensate for the high risk. Venture capital may be regarded as an equity investment where investors expect significant capital gains in return for accepting the risk that they may lose all their equity (Golis, 1998).

The Nigerian government's version of venture capital financing of SMEs -SMIEIS, requires all licensed banks in Nigeria to set aside $10 \%$ of their pre-tax profit for equity investment and to promotion of small and medium-scale enterprises. The goal is to reduce interest rate burden and other financial service charges imposed under normal bank lending.

According to Sanusi (2004), a breakdown of the SMIEIS fund investment by sectoral distribution shows that $68.82 \%$ went to the real sector while service related investment accounted for $31.18 \%$. This, he noted, is a sharp reversal from the initial trend recorded under the scheme. The Bankers Committee have allocated the investment of banks with respect to the fund as $60 \%, 30 \%$, and $10 \%$ of their fund in core/real sector, service-related and micro-enterprises respectively. Analyzing the geographical spread of the SMIEIS fund, Sanusi (2004) reported that Lagos-based investments have gulped $56.63 \%$ of the fund, and Abuja and 18 states received the balance $43.47 \%$.

The point is about the model of growth of SMEs and financing options available with respect to corporate governance. Golis (1998) submit that venture capitalists do not seek enterprises on the start-up and survival stage but only in the stability and rapid growth stages did the venture capitalists appear which goes to show their fear because of the risk associated with the early stages. Yet the method of financing remains a critical success factor for SMEs.

To be eligible for equity funding under the scheme, a prospective beneficiary shall: i). Register as a limited liability company with the Corporate Affairs Commission and comply with all relevant regulations of the Companies and Allied Matters Act (1990) such as filling of annual returns, including audited financial statements; ii).Comply with all applicable tax laws and regulations and render regular returns to the appropriate authorities (Bankers Committee Revised, 2005).

Aruwa (2005) laments that, given the developmental stage of Nigeria's dominant SMEs; it is difficult for them to meet 
any of these requirements. Consequently, SMEs in Nigeria do not have the capacity to access funds from SMEEIS.

With proper identification of risk exposure and then managing them, our Nigerian dominant SMEs will position themselves as good investment opportunities and become attractive for all available schemes to part with their funds to them.

\section{Methodology}

This study is designed to look at financing options available to SMEs in Nigeria and to identify the one that is most explored and why. The study also wishes to further establish that good risk management and insurance cover can lesson their risky nature and repackage them attractively for investment. To achieve this purpose, the survey research design and an empirical method making use of Chi-square and correlation was used. Chi-square was used to test hypothesis concerning issue of good risk management and insurance cover. Correlation was used to substantiate whether there is similarity in the identified problems of each financing option. Mean scores using 5 point likert scale was used to present and analyze the collected data via questionnaire. Simple percentages were also used to put together the data concerning responses about the financing mix of sampled SMEs. The questionnaire is used to obtain the views of the owners of SMEs on risk management and insurance cover.

The population of this study is made up of 700 SMEs with a minimum of five year life span operating within Benue and Nasarawa States. The study's sample size is 88 SMEs made up of 43 from Nassarawa state divided into 30 small-scale enterprises and 13 medium-scale enterprises. Similarly 45 SMEs were drawn from Benue State divided into 34 small-scale enterprises and 11 medium-scale enterprises. Unfortunately only 40 completed questionnaires were returned from Nasarawa made up of 28 small-scale enterprises and 12 medium-scale enterprises. Similarly, only 44 questionnaires were returned from Benue State made up of 33 small-scale enterprises and 11 medium-scale enterprises. The sample size was, therefore, limited to 84 SMEs.

The research sample was computed using the following formula, allowing $10 \%$ tolerable sample error. Sample Formula $(\mathrm{n})=\mathrm{N} / 1+\mathrm{N}(\mathrm{e})^{2}$, where $\mathrm{n}$ is the required sample size, $\mathrm{N}$ is the research population, and e is the tolerable error in judging the population. Primary data were obtained using questionnaire designed for SMEs and financing institutions separately and structured interview instruments. The questionnaire employs likert-scale measures, a fifteen likert-like scale having four response categories labeled or weighted as strongly agree (4), agree (3) disagree (2) and strongly disagree (1).

\section{Data Presentation, Analysis and Interpretation}

\subsection{Analysis and Interpretation of Responses on Formal Financing}

The responses from the questionnaire administered in respect of formal financing sources available to SMEs in $\mathrm{Ni}$ geria are presented and analyzed below:

In the analysis presented in table 1 , none of the formal financing variables meet the cut-off mean of 2.5 for individual item. Respondents perceived that the utilization rate of formal financing sources among the SMEs sampled was low. The overall perception of formal financing sources that emerge from this analysis, therefore, is that there is low utilization rate of formal financing sources by SMEs in $\mathrm{Ni}$ geria given that the computed overall mean score of the variables (6.06) is less than the sections cut-off mean of 12.5 . The standard deviation (3.65) shows that there is no much disparity in the respondents' perception as evidenced in the mean scores the formal financial options are relatively organized and would want to deal with an enterprise that is as well organized. Corporate governance can portray an SME as organized in the eyes of stakeholders especially fund providers to enable them secure the desired funding. This low utilization of this option could be as a result of poor governance hence a risky venture.

Table 2 depicts a favorable perception on utilization of informal financing sources than the data presented in Table1. The cooperative credit has the highest mean score of 3.91. What is significant in the table is that the SMEs' mean score of 14.68 on informal sources of finance is higher than the section's cut-off mean of 12.5 . The disparity in perception as indicated by the standard deviation is low. Comparatively, the mean scores recorded for formal sources of finance in Table 1 was 1.34 . This is less than the mean score of 3.86 recorded for informal sources of finance (Table 2). This is interpreted that informal sources of finance are more available and more utilized by SMEs in Nigeria than the formal sources. Relations, cooperative credits are all from people within immediate or extended family cycles their based on "loose" trust. In an organize setting, business is run on lay down rules not loose trust. It could be for this reason that this informal financial option is embraced more by SMEs in Nigeria.

The study investigated what could be the likely financing problem that brought about deviation in the use of both formal and informal financing sources. Table 3 provides the analysis along five variables on likert scale measures. The formal sources of finance combined mean score (13.99) on the cost, accessibility to source of finance, collateral security requirement, awareness of existence of sources of finance and the risk inherent in use is higher than the cut-off mean whereas the cut-off mean on informal sources, which is within acceptable mean score $(9.82<12.5)$. However, the informal sources of finance mean score on awareness is lower than that of the formal sources. This could mean that the existence of formal sources of finance like SMEEIS is not to the knowledge of most SMEs.

A further test of correlation between the mean scores of 
formal and informal sources of finance shows negativelycorrelated relationship of -0.5000 on the variables of financing problems. This is shown in Table 4 below: It is no doubt that there is a relationship between formal and informal sources of finance as far as SME financing is concerned. The calculation of correlation coefficient $(r)$ revealed an average negative relationship between these variables. This could be explained that accessibility may be a problem more of the formal sources than of the informal sources. Similarly, the level at which collateral is demanded in formal sources is not the same as in an informal source. A positive correlation coefficient would on the other hand mean, the more collateral is needed in formal source, the more it is needed also in an informal source. The negative correlation therefore, shows that the variables move on average in the opposite direction.

\subsection{Test of Hypothesis 1}

Table 5: depicts the percentage of the formal and informal

Table 1. Mean Scores on Formal Financing Sources

\begin{tabular}{|c|c|c|c|c|c|}
\hline Variable & Sample size & Mean & Standard Deviation & Minimum Score & Maximum Score \\
\hline Formal finance as main source of Capital & 84 & 1.34 & 0.71 & 4.00 & 1.00 \\
\hline Bank loan & 84 & 1.33 & 0.69 & 4.00 & 1.00 \\
\hline Second-tier Security market (SSM) & 84 & 1.00 & 1.18 & 0.00 & 0.00 \\
\hline SMEEIS & 84 & 1.20 & 0.57 & 4.00 & 1.00 \\
\hline Others & 84 & 1.19 & 0.50 & 3.00 & 1.00 \\
\hline Combined Mean/SD score & 84 & 6.06 & 3.65 & \multicolumn{2}{c|}{$6.06<12.5$} \\
\hline
\end{tabular}

Source: Field data computation (November, 2009)

Table 2. Mean Scores on Informal Financing Sources

\begin{tabular}{|c|c|c|c|c|c|}
\hline Variable & Sample size & Mean & Standard Deviation & Minimum Score & Maximum Score \\
\hline Informal finance as main source of Capital & 84 & 3.86 & 0.48 & 1.00 & 4.00 \\
\hline Personal Savings & 84 & 3.60 & 0.82 & 1.00 & 4.00 \\
\hline Cooperative Credits & 84 & 3.91 & 3.39 & 1.00 & 4.00 \\
\hline Loans from Friends/Relatives & 84 & 1.96 & 1.28 & 2.00 & 1.00 \\
\hline Ploughed-back profits & 84 & 1.35 & 0.87 & 2.00 & 4.00 \\
\hline Combined Mean/SD score & 84 & 14.68 & 6.84 & \multicolumn{2}{|c|}{$14.68>12.5$} \\
\hline
\end{tabular}

Source: Field data computation (November, 2009)

Table 3. Mean Score on Financing Problems

\begin{tabular}{|c|c|c|c|}
\hline Variable & Sample size & Formal Sources & Informal Sources \\
\hline Cost & 84 & 2.02 & 1.03 \\
\hline Accessibility & 84 & 31 & 3.71 \\
\hline Collateral & 84 & 3.38 & 2.62 \\
\hline Awareness & 84 & 2.57 & 1.36 \\
\hline Risk (others) & 84 & $13.99>12.5$ & $9.82<12.5$ \\
\hline
\end{tabular}

Source: Field data computation (November, 2009)

Table 4. Correlation Coefficient of Financing Problem Variables

\begin{tabular}{|c|c|c|}
\hline Variable & Mean \\
\hline & Formal Sources & \multicolumn{2}{|c|}{ Informal Sources } \\
\hline Cost & 2.02 & 1.03 \\
\hline Accessibility & 1.31 & 3.71 \\
\hline Collateral Security & 3.71 & 1.62 \\
\hline Awareness & 3.38 & 2.10 \\
\hline Risk (others) & 2.57 & 1.36 \\
\hline
\end{tabular}

Source: Field data computation (November, 2009) component sources of financing in the capital structure of the small enterprise's capital and 70\% of medium ente capital respectively. None of the enterprises secured capital from the Second-Tier Security Market (SSM). Cooperative constituted the highest contribution to the capital of cesterprises accounting for $31 \%$ and $33 \%$ in the small

\section{Test of Hypothesis 2}

Good management and adequate insurance cover for

Chi-square was used to test this hypothesis. The data used Questionnaire. The summary of the responses are presented in the table below: 
Table 5. Sampled SME Financing Mix

\begin{tabular}{|c|c|c|}
\hline Source of Finance & Small Enterprise (percentage of Total Capital) & Medium Enterprise (percentage of Total Capital) \\
\hline Formal Sources & 32 & 30 \\
\hline Bank loans & 04 & 24 \\
\hline NDE/NACRDB & 25 & 00 \\
\hline SMIEIS & 03 & 05 \\
\hline SSM & 00 & 00 \\
\hline Equipment Leasing & 00 & 01 \\
\hline Informal Sources & 68 & 70 \\
\hline Personal Savings & 20 & 23 \\
\hline Cooperative Loans & 31 & 33 \\
\hline Loan from friends/ Relatives & 15 & 12 \\
\hline Others & 02 & 02 \\
\hline
\end{tabular}

Source: Interview Questionnaire Responses (November, 2009).

Table 6. Responses from Question 17 of the Questionnaire

\begin{tabular}{|c|c|c|}
\hline Respondents & Responses \\
\hline & Poor risk management & Other reasons \\
\hline Bank managers & 56 & 5 \\
\hline Senior staff Ministry of Commence and Industry & 20 & 3 \\
\hline Total & 76 & 81 \\
\hline
\end{tabular}

The above shows that a total of 56 Bank managers from Nasarawa and Benue States lamented that poor risk management of SMEs are responsible for their reluctance in funding SMEs, while five other managers from the two states attributed their reluctance to other reasons. In the same vein, a total of 20 senior staff of the Ministries of Commence and Industry from the two state under which SMEs are registered and monitored confessed that poor risk management and lack of insurance cover is prevalent in the predominant SMEs while three of these category of staff from this ministries gave other relative reasons why funding is still a problem for most SMEs. On the whole 76 Bank managers from the two states are of the opinion that the absence of risk management in SMEs in Nigeria is the reason for their reluctance in funding them, while 8 Senior staff of the ministries under which SMEs are registered and monitored are affirmatively said poor risk is one key reason for the persistent funding crises of SMEs in Nigeria.

If the calculated chi-square $\left(\mathrm{X}^{2}\right)$ is greater than the table value (critical value), the difference is significant, and so the null hypothesis is rejected. But if $\mathrm{X}^{2}$ is less than the table value, the difference is insignificant, and so the null hypothesis is accepted.

The critical value of $\mathrm{X}^{2}$ at $0.051 \mathrm{df}$ is 3.841 . The calculated value in this case 0.73 which is less than the critical value. Therefore the difference is insignificant and so the null hypothesis, which states that good risk management and adequate insurance cover for SMEs will help improve their funding, is accepted.

\subsection{Discussion of Findings}

Table 5 shows that bank lending to small-scale enterprises in Nigeria was just four percent of the total finance of the sector during the period under review. This is at variance with the pecking order theory or hypothesis which implies that banks should lend to SMEs where they have exhausted their retained earnings to finance their investment. SMEs by their nature cannot raise substantial internal finance. It, therefore, becomes necessary for them to seek bank lending to bridge the gap between their retained earnings and their potential investment outlay. The way banks look at the SMEs is therefore very important in this circumstance.

Table 5 also shows that bank lending to medium-scale enterprises was $24 \%$ of the total finance of the sector, which is relatively higher than the figure for small-scale enterprises. This is also at variance with the pecking order theory. Going by the theory, it is to be expected that small-scale enterprises should get more bank loans than medium-scale enterprises since they can raise more internal finance than small-scale enterprises. It could, therefore, be inferred from the above that banks in Nigeria only lend to enterprises that show some sense of maturity in the way their affairs are run, and have high potentials to repay loans which translates into being less risky. With this type of philosophy, they can hardly support small-scale enterprises until there is evidence of improvement in the way they are run. Since SMEEIS comprise banks, this behavior of banks can be rightly said to represent the behavior of SMEEIS (Azende, 2011a).

The factors that have favored informal financing of SMEs in Nigeria over the formal financing were cost of finance, ease of accessibility, nature of collateral security and risk mitigation capacity. It is evident from the study that it costs SMEs less interest charges on borrowings from informal sources than prevailing rates in the formal sources. Whereas accessibility to informal sources of finance was less a problem, it was still difficult for SMEs to access funds from the formal sources because of stringent collateral security requirement and inadequate risk mitigation schemes for the formal sources of finance. In the informal sources, individual's reputation and community acceptance or cooperative society membership were sufficient to access the funds for business purposes. 
Risk management and insurance cover is not only for big companies. SMEs also have stakeholders like fund providers, employees, the government etc. wherever there are stakeholders, an organization must run in a manner to give hope for continuity. Decisions must be in line with long term survival strategies hence growth, development and sustainability of such organizations and the Nigerian economy at large.

\section{Conclusions and Recommendations}

It is obvious that a dynamic SME sub-sector is needed for Nigeria to attain industrialization and sustainable economic development and for its Vision 20-20-20 to be achieved. This subsector is, therefore, vital and imperative for the actualization of Nigeria's vision. The observed weak performance of notable formal financing options, like SMEEIS, occasioned by lingering constraints should, however, be seen as a big challenge for policy makers in the country. This study hereby reveals the following major findings:

$>$ The financing mix of SMEs in Nigeria is predominantly from informal sources of finance. This is shown by the use of this option more than the formal sources by the SMEs. Cooperative credit ranks highest in this category while the second-tier security market (SSM) is left un-patronized.

A comparative analysis of the inherent problems of the formal and informal sources of finance to SMEs shows that the formal sources are inherently more problematic to SMEs in Nigeria than the informal sources.

$>$ Most of the banks in the country do not pay sufficient attention to the development of SMEs via financing because of their risky nature.

$>$ The following recommendations are hereby made in response to the above findings:

$>$ Banks, by their nature and in line with their objective, do try to minimize risk; while SMEs, on the other hand, are inherently risky. Consequently, the government and the banks should mutually agree on a credit guarantee scheme that will incorporate a risk-sharing arrangement as a way of encouraging banks to channel funds to SMEs.

$>$ Capacity building and sensitization programmes for all registered SMEs should be put in place by government to train them on the necessity for identifying their risks and how to categorize them and take adequate insurance cover

$>$ Diversification of financial support for start-ups (more risky), growing and successfully operating SMEs will significantly contribute to the creation and development of SMEs. Start-ups, growing and successful SMEs should get $50 \%, 30 \%$ and $20 \%$, respectively of whatever financial support is available for SMEs.

$>$ There should be steady programme on radio and television in an attempt to report to the whole world the efforts of Nigerian SMEs in improving their general conduct so that their maturity can be assessed hence reduce the perceived risks.

\section{REFERENCES}

[1] Aernold, R. (1998), "Round table discussion on recommendations for best practice in financial intermediaries for SMEs", in: Final Report of Expert Meeting on Best Practice in Financing SMEs. United Nations/ECE, Geneva, Switzerland, May.

[2] Agumagu, A.C. (2006), 'Finance for Industry and Commerce', The Business of Banking, Lectures and Proceedings at the 26th International Banking Summer School, Oxford.

[3] Akabueze, B. (2002), 'Prospectus on Nigeria SMEs under the Small and Medium Industries Investment Scheme (SMIEIS)'. Accessed August 142009 from

www.nigeriabusinessinfor.com/nigerian-smes2000.htm .

[4] Aladekomo, F.O. (2003), "The Small and Medium Enterprises' (SME) Landscape: Environment, Government Policies, programmes, and Institutional Support", A paper delivered at the two-day workshop on "Strategies for Operationalizing Small and Medium Industries Equity Investment Scheme (SMIES) in Nigeria" on 23-24 August, 2003, at WEMA Bank Training School, Oba Akran Avenue, Ikeja, Lagos, Nigeria.

[5] Anic, V. and Paus, V.(1998). 'The Croatian SME study: Best practice in Financing SMEs in SECI and CEI Countries'In: Final Report of UN/ECE Expert Meeting on Best practice in Financing SMEs. Geneva

[6] Ariyo, D. (2005), 'Small firms are the backbone of the Nigerian economy', Accessed August 14, 2009 from www.africaneconomicanalysis.org.

[7] Aruwa, S.A.S (2004), 'Financing options for small and medium-scale enterprises in Nigeria', The Nigerian Journal of Accounting and Research, Department of Accounting, Ahmadu Bello University, Zaria. Vol.1, No.2, June.

[8] Aruwa, S.A.S (2005), The Business Entrepreneur: A Guide to Entrepreneurial Development. Kaduna: Scopy Publishing.

[9] Augusto, O. (2004), 'Beyond bank consolidation effects on banking and real sectors', CBN 4th Annual Monetary Policy Conference, 18-19th Nov. p. 83-85.

[10] Azende, T. (2011a) Corporate Social Responsibilities in Nigeria Banking System: the development of Small and Medium Scale Enterprises. World Journal of Social Science vol.1; No.5 Pp.12-28.

[11] (2011b) An assessment of the financing options available to Small and Medium Scale Enterprises (SMEs) in Nigeria. World Review of Business Research vol.1; No.5 Pp.13-28.

[12] (2011c) An Empirical evaluation of Small and Medium Enterprises Equity Investment Scheme in Nigeria. Journal of Accounting and Taxation vol.5 (7).

[13] Bankers Committee (2005), Revised Operational Guidelines for the Operation of Small and Medium Enterprises Equity Investment Scheme (SMEEIS).

[14] Central Bank of Nigeria (CBN) (2000), 'The changing structure of the Nigerian economy and implications for development', August 2000. Realms Com ltd Lagos, pp. 61-97. 
[15] Douglas, H. (2009) The failure of risk management: why its broken and how to fix it. John Wiley.

[16] Ekpenyong, D.B.E. and Nyong, M. O. (1992), 'Small and medium-scale enterprises development In Nigeria'. Seminar Paper on Economic Policy Research for Policy Design and Management In Nigeri. NCEMA/AEPC, Nigeria, April 24-25.

[17] Gelinas, J.B. (1998), Freedom from Debt: The re-appropriation of development through financial self-reliance. Dhaka-Ottawa: University Press.

[18] Golis, C. (1998), Enterprise and Venture Capital: A Business Builder and Investment Handbook, 3rd edition, Australia: Allen and Urwin

[19] Honourary Presidential Advisory Council on Investment in Nigeria (HPACI, 2002), Sectoral Profiles on Small and Medium Scale Enterprises. Vol. I and II, May.

[20] Inang, E.E. and Ukpong, G.E. (1992), 'A review of small-scale enterprises credit delivery strategies in Nigeria'. Economic and Financial Review. CBN, Vol.30 No.4, December.

[21] Kpelai,T. (2009), Entrepreneurship development in Nigeria, Makurdi: Aboki Publishers.

[22] Mainoma, M.A. (2005), 'The nexus between risk and investment decision: Experiences from Nigerian investment climate', Nigeria Journal of Accounting Research, Department of Accounting, ABU, Zaria. No. 3 Dec., 2005. p. 64.

[23] Mambula, C. (2002), 'Perceptions of SME growth constraints in Nigeria'. Journal of Small Business Management, Vol. 40 (1), pp. 58-65.

[24] McRichie, J., (1997). “Corporate Governance. A commentary on Corporate Governance". Retrieved from http://www.copgov.net/commentary/ending.html

[25] Njoku, S. (2007), 'The capital flight challenge for the Nigerian industrial sector'. Real Sector Digest, Business Day, August 15.
[26] Oboh, G. A. T., (2004). "Contemporary Management Practice and Challenges to Banking Business in Nigeria". Union Digest $8,1-22$.

[27] Ohanga, M. (2005), 'Bank lending practices to small and medium sized enterprises'. Retrieved November11, 2009 from http://www.med.govt.nz/templates/MultipageDocumentPage -971

[28] Ojo, A.T. (1984), Banking In Nigeria, London: Graham Burn.

[29] Sanusi, J. (2004), 'Research study presentation at the National summit on revamping small and medium industries', This Day. Vol. 10, No. 3243, page 25.

[30] Schneider-Barthold, W. (2002), 'Africa's aborted industrialisation: Modernisation strategies impede organic industrial growth'. D+C Development and Cooperation (No. 1, January/February, P. 15-17), Deutsche Stiftung Fur Internationale Entwicklung (DSE), Germany.

[31] Sheikh, S. and Chatterjee, S. K. (2000), "Perspective on Corporate Governance", in S. Sheikh and W. Rees (eds.), Corporate Governance \& Corporate Control, London: Cavendish Publishing Limited.

[32] Starmans, R. (1998), 'Dutch SME credit guarantee scheme Best practice in financing SMEs in advanced market economies In: Final Report Of Expert Meeting On Best Practice In Financing SMEs. United Nations/ECE, Switzerland, May.

[33] Sule, E.I.K. (1986), 'Small scale industries in Nigeria: Concepts, appraisal of government policies and suggested solutions to identified problems', CBN Economic and Financial Review, Vol. 24, No. 4.

[34] Vaughan, E. J. (1997) Risk Management, New York: wiley

[35] World Bank (1995), 'Private sector development in low income countries', Washington, D.C 